\title{
Pengaturan Kewenangan, dan Tanggung Jawab Direksi Dalam Perseroan Terbatas (Studi Perbandingan Indonesia dan
}

\author{
Australia)
}

0leh

Shinta Ikayani Kusumawardani

(Konsentrasi Hukum Bisnis FH-Unud)

\begin{abstract}
Research on: The Rules Regarding The Powers and Responsibilities Of Directors In A Limited Liability Company (Comparative Study of Indonesia and Australia). As for the issues discussed in this study related to the application of the authority of the board of directors in the management of a limited liability company under the principle of fiduciary duty Australia comparison of Indonesia can not be separated from the authority granted will cause responsibility that must be borne by the company's board of directors in managing and also the characteristics of the type of responsibility of Directors

This study uses normative juridical approach. Juridical Approaches to run whether the provisions of law relating to kewenagan concrete and responsibilities of the Board of Directors in the management Company Limited Comparative Study of Indonesia and Australia, while Normative is the cover of the principles of law, comparative law, the elements and factors related to authority and responsibility of the Company's Board of Directors in the management of one heart-to-day. This study on Duties and Responsibilities of Directors is normative legal research that emphasizes the study of literature. The purpose of this research is to know the duties and responsibilities of the Board of Directors of Limited Liability Company under the law. Data analysis was performed using the comparative method of qualitative. From the results of this analysis are expected to obtain an accurate picture and understanding of the duties and responsibilities of the Board of Directors of Limited Liability Company.

To this effect, a comparison of the authority and responsibilities of the Board of Directors in the management of the Company as the Company's
\end{abstract}


assessment of body organ is the comparison between the authority of the Board of Directors in Indonesia and in Australia the comparative results indicate that the system of regulation in Indonesia and Australia are more inclined to use the model and not a model enabling mandatory because it is based by the condition of the structure of capital ownership. Fiduciary obligations, particularly on legislation in both Indonesia and Australia appear as incomplete law and need to be interpreted by the fiduciary.

The main essence of this comparison as the basis for further transplants Indonesia that fiduciary obligations may fruitfully dalamn Handling Company Limited.

Keywords: Authority and Responsibility of the Board of Directors, Company Limited.

\section{PENDAHULUAN}

\subsection{Latar Belakang}

Keberadaan

Perseroan

Terbatas dalam dunia usaha dan perdagangan baik secara nasional mapun secara internasional adalah sangat penting serta strategis untuk menggerakkan dan mengarahkan kegiatan pembangunan ekonomi, terutama dalam rangka menghadapi globalisasi dan liberalisme perekonomian dunia yang semakin kompleks, sehingga para pelaku bisnis lebih cenderung memilih badan usaha yang berbentuk badan hukum yaitu Perseroan Terbatas, alasannya sebagaimana dikemukakan oleh Sri Rejeki Hartono bahwa :

Perseroan

mempunyai kemampuan untuk mengembangkan diri, mampu mengadakan kapitalisasi modal dan sebagai wahana yang potensial untuk memperoleh keuntungan baik bagi instansinya sendiri maupun bagi para pendukungnya (pemegang saham). Oleh karena, itu bentuk badan usaha ini Perseroan Terbatas sangat diminati oleh masyarakat. ${ }^{1}$

Adapun Rudhi Prasetyo mengemukakan alasan pelaku bisnis memilih Perseroan Terbatas adalah :

Sebagai badan hukum yang mandiri pada hakekatnya Perseroan Terbatas mempunyai tanggung jawab terbatas dimana konsekuensinya segala akibat dan hutang yang timbul dari perbuatan tersebut harus

\section{${ }^{1}$ Agus Budiarto, 2002,Kedudukan} Hukum Tanggung Jawab Pendiri Perseroan Terbatas, Cet. I, Ghalia Indonesia,Jakarta, hal. 13 
ditanggung oleh Perseroan Terbatas itu sendiri yaitu dengan harta kekayaan Perseroan Terbatas yang bersangkutan tanpa sedikitpun dapat meminta pertanggungjawaban dan atau menuntut untuk dibayar dari harta kekayaan pribadi yang melakukan perbuatan sekalipun yang melakukan perbuatan adalah pemegang Perseroan Terbatas. $^{2}$

Dari pengertian diatas dapat disimpulkan bahwa Perseroan Terbatas merupakan suatu badan hukum (rechtpersoon, legal entity), atau suatu manusia semu (artificial person) ataupun merupakan suatu badan hukum intelektual (intellectual body). Pada prinsipnya yang bertanggungjawab atas kegiatan yang dilakukan oleh perseroan adalah perseroan itu sendiri selaku badan hukum $^{3}$. Namun mengingat Perseroan Terbatas adalah suatu

\footnotetext{
${ }^{2}$ Rudhi Prasetya, Kedudukan Mandiri Perseroan Terbatas disertai dengan ulasan menurut UU No, 1 tahun 1995 tentang Perseroan Terbatas, Cet,ke I, PT Citra Aditya Bakti, Bandung, 1995, hal. 50.

${ }^{3}$ Munir Fuady, 2008,Perseroan Terbatas Paragdigma Baru, Cetakan 3, PT Citra Aditya Bakti, Bandung, hal.8. (selanjutnya disingkat Munir Faudy I)
}

badan hukum atau suatu subyek hukum yang memiliki hak dan kewajiban baik secara phisik dan phsikis tidak dapat bertindak sendiri maka perlulah diwakili dengan sah, oleh organ perusahaan yang oleh hukum ditunjuk guna mewakili hak dan kewajiban Perseroan Terbatas adalah Direksi sebagaimana diatur dalam Pasal 92 UU No. 40 Tahun 2007.

Direksi merupakan organ Perseroan yang berwenang dan bertanggung jawab penuh atas pengurusan Perseroan untuk kepentingan Perseroan sesuai dengan maksud dan tujuan Perseroan serta mewakili Perseroan baik di dalam maupun di luar pengadilan sesuai dengan Anggaran Dasar berdasarkan sistem hukum Indonesia. Dalam hal ini dikaji dalam hukum comman law system dimana seorang Direksi memiliki kewenangan dan tanggung jawab yang terbagi dalam dua hal yaitu :

1.Kewajiban yang berlandaskan prinsip fiduciary dengan iktikad baik dan tanggung jawab. 
2. Kewajiban pengurusan yang baik dan bertindak dengan keahlian dalam Perseroan.

Sehingga dalam hal ini Direksi memiliki kedudukan serta perannya sebagai organ Perseroan dan tugasnya mencakup kewenangan dalam hal tanggung jawabnya sebagai organ Perseroan. Direksi memiliki kewajiban untuk menjalankan pengurusan Perseroan sesuai dengan iktikad baik dan pengabdian terhadap Perseroan sesuai dengan tujuan dari Perseroan yang tertuang dalam Pepektus perusahaan. Sehingga apabila terjadi kesalahan terhadap penjabaran perpektus perusahaan Direksi dapat langsung dimintakan pertanggunjawabannya akan tetapi selama Direksi dapat membuktikan bahwa kelalaian tersebut bukan disebabkan oleh kesalahan dirinya maka Direksi dapat dibebaskan dari tanggung jawab tersebut. Dengan adanya perbedaan sistem hukum yang mengatur hukum perusahaan dari kedua sistem yang berbeda ini mengakibatkan adanya persamaan dan perbedaan kewenangan serta tanggung jawab dari seorang Direksi.
Direksi sebagai organ penting dalam Perseroan selaku pengurus dan perwakilan perseroan, harus bertindak secara hati-hati, patut dan bertindak dengan itikad baik dan penuh tanggung jawab sesuai dengan anggaran dasar perseroan sebagaimana dengan maksud dan tujuan perseroan yang dipimpinnya. Kepercayaan (fiduciary) untuk menjalankan dan mengelola perseroan sesuai dengan maksud dan tujuan perseroan Direksi mengendalikan operasi kegiatan perseroan sehari-hari dalam batasbatas yang ditetapkan oleh UndangUndang Nomor 40 Tahun 2007 tentang Perseroan Terbatas, Anggaran Dasar dan RUPS serta di bawah pengawasan Dewan Komisaris. Apabila dalam melakukan tugas dan tanggung jawabnya, serta wewenang, Direksi melakukan perbuatan melawan hukum yang mengandung benturan kepentingan atas kepentingan pribadi dan kepentingan perseroan, Direksi tersebut harus lebih mendahulukan kepentingan perseroan. Direksi dapat mengambil kepentingan tersebut, sepanjang tidak merugikan perseroan, artinya tidak ada menimbulkan kerugian terhadap perseroan atas tindakan yang diperbuat oleh Direksi. 
The American Law Institute Principles of Corporate Governance that provision would insulate a director or officer from liability for the consequences of a business judgement if, in addition to exercising due and acting in good faith, he had a rational basis for business judgement. ${ }^{4}$ Pada umumnya dalam sistem common law Board of Directors, dibagi menjadi dua bagian yaitu:

1. Chief Executive officer (CEO), yang berfungsi dan bertanggung jawab melaksanakan pengurusan Perseroan sehari-hari.

2. Chairman, berkedudukan sebagai Direktur noneksekutif (non-executive director).

Pengangkatan noneksekutif direktur terutama diperlukan pada Perseroan besar maupun Perseroan Publik. Umumnya mereka memiliki keterampilan dan pengalaman dalam

\footnotetext{
${ }^{4}$ Dikutip dalam The American Law Institute Principles of Corporate Governance oleh Munir Fuady, 1996,Hukum Bisnis Dalam Teori dan Praktek buku ke satu, PT Citra Aditya Bakti, Bandung, hal62. (selanjutnya disingkat Munir Faudy II)
}

kedireksian. Mereka harus merupakan elemen yang bersikap independen dan objektif dalam mengambil keputusan dalam melakukan pengawasan jalannya Perseroan, khususnya dalam menyelesaikan benturan kepentingan (conflict of interest) antara Executive Directors dengan kepentingan lain. Mereka dapat dikatakan berperan secara independen sebagai "anjing penjaga" (watch dog) untuk kepentingan pemegang saham minoritas.

Berdasarkan pemahaman terhadap konsep dasar tanggung jawab Direksi dalam menjalankan Perseroan Terbatas seperti di jelaskan tersebut di atas, maka akan di bahas dalam jurnal ini dengan judul "Pengaturan Kewenangan, dan Tanggung Jawab Direksi Dalam Perseroan Terbatas (Studi Perbandingan Indonesia dan Australia)."

\subsection{Rumusan Masalah.}

Berdasarkan uraian latar belakang masalah tersebut diatas, maka dapat dirumuskan permasalahan sebagai berikut: 
1. Bagaimanakah kewenangan

Direksi dalam menjalankan

Perseroan Terbatas?

2. Bagaimanakah tanggung jawab hukum Direksi dalam pengurusan Perseroan Terbatas serta terkait penerapan Corporate Social Responsibility?

\subsection{Tujuan Penelitian.}

Upaya peneliti untuk pengembangan ilmu hukum terkait dengan paradigma "science as a proces " (ilmu sebagai proses). Dengan paradigma ini ilmu tidak akan pernah berhenti atau bersifat final dalam penggaliannya atas kebenaran dibidang obyeknya masing-masing. ${ }^{5}$ Secara umum penelitian ini bertujuan antara lain yaitu :

1. Untuk dapat mengetahui batasan dan mengungkapkan bahwa landasan transplantasi prinsip fiduciary dalam sistem hukum Indonesia dan Australia, terkait dengan

${ }^{5}$ Pedoman Penulisan Usulan Penelitian dan Penulisan Tesis Ilmu Hukum Program Studi Magister Ilmu Hukum Program PascaSarjana, 2006,UNUD, hal. 7. kewenangan Direksi dalam

Perseroan sehingga dapat memperdalam hukum kita sendiri, serta dapat meneliti secara obyektif kelebihan dan kekurangan hukum kita sendiri sehingga kita dapat melihat kemungkinan-kemungkinan pengaturan problem sosial.

2. Untuk dapat mengetahui kriteria tanggung jawab Direksi terkait dalam pengurusan Perseroan Terbatas dalam studi banding antara Indonesia dan Australia.

\section{Metode Penelitian}

Pendekatan masalah yang dipakai adalah metode pendekatan masalah secara yuridis normatif yaitu pendekatan yang mencakup penelitian terhadap asas-asas hukum, perbandingan hukum, unsur-unsur dan faktor-faktor yang berhubungan dengan kewenangan dan tanggung jawab direksi dalam Undang Undang Perseroan Terbatas dengan perbandingan sistem hukum Common Law. Comparative Approach (Pendekatan Perbandingan), maksudnya kegiatan 
untuk membandingkan hukum suatu negara dengan hukum negara lain atau hukum dari suatu waktu tertentu dengan hukum dari waktu yang lain. ${ }^{6}$ Jadi dengan pendekatan ini dapat kita dapat kita dapat meneliti secara obyektif kelebihan dan kekurangan hukum kita sendiri, sehingga kita melihat kemungkinan-kemungkinan pengaturan problema-problema social yang berkaitan dengan kewenagan dan tanggung jawab Direksi dalam pengurusan Perseroan Terbatas terutama dalam tanggung jawab sosial dan lingkungan.

Penelitian yuridis normatif, teknik pengumpulan bahan hukum yang digunakan dalam penelitian ini adalah melalui penelitian kepustakaan (library research) upaya untuk memperoleh bahan dari dari penelusuran literatur kepustakaan, peraturan perundangundangan,majalah/jurnal hukum, koran dan majalah serta artikel online dalam halaman internet dan sumber lainnya yang ada kaitannya dengan pembahasan topik tesis ini yaitu kewenangan dan tanggung

\footnotetext{
${ }^{6}$ Peter Mahmud Marzuki,2007, Penelitian Hukum, Jakarta,hal. 133.
}

jawab Direksi dalam studi banding Indonesia dan Australia.

\section{HASILDAN PEMBAHASAN 3. KEDUDUKAN DAN KEWENANGAN DIREKSI DALAM PERSEROAN TERBATAS.}

Kedudukan Perseroan Terbatas sebagai badan hukum tidak bisa dilepaskan dari teori fiksi (fictie theorie) yang dikenal dalam ilmu hukum. Teori ini dikemukakan pertama kali oleh Von Savigny. Menurut teori ini, badan hukum itu dianggap sebagai hal yang abstrak, tidak nyata, karena tidak mempunyai kekuasaan untuk menyatakan kehendak. Badan Hukum dianggap seolah-olah manusia. Oleh karena itu, tindakan badan hukum dianggap juga sebagai tindakan manusia. Jika manusia dalam tindakannya mempunyai tanggung jawab, badan hukum juga bertanggung jawab atas tindakan yang dilakukannya.

Perseroan Terbatas sebagai badan hukum merupakan pendukung hak dan kewajiban, yang dapat mengadakan perbuatan hukum dengan pihak lain. Perseroan 
Terbatas memiliki kekayaan sendiri, yang terpisah dari kekayaan pengurus atau pendirinya. Segala kewajiban hukumnya dipenuhi dari kekayaan yang dimilikinya itu. Menurut asasnya apabila kekayaan perseroan tidak mencukupi untuk menutupi kewajibannya, maka hal tersebut bukan berarti tanggung jawab pendiri atau pengurus untuk menutup kekurangan tersebut. Badan hukum merupakan subjek hukum buatan manusia berdasarkan hukum yang berlaku.

Direksi ini bertindak untuk dan atas nama Perseroan, sehingga bertanggung jawab penuh atas pengurusan perseroan untuk kepentingan dan tujuan perseroan dan sebagai wakil dari Perseroan baik di dalam maupun di luar pengadilan sesuai dengan Anggaran Dasar.

Direksi adalah organ perseroan yang bertanggung jawab penuh atas pengurusan perseroan untuk kepentingan perseroan dan tujuan perseroan baik di dalam maupun di luar pengadilan sesuai dengan ketentuan Angaran Dasar. Direksi merupakan satu-satunya organ dalam perseroan yang melaksanakan fungsi perseroan. ${ }^{7}$ Direksi merupakan organ yang bertindak untuk melakukan pengurusan dan pengawasan suatu perseroan yang berkewajiban untuk meningkatkan nilai ekonomis suatu perseroan termasuk pengurusan sehari-hari, sehingga Direksi harus diberikan kewenangan-kewenangan yang mendukung untuk tercapainya hasil yang ingin dicapai dalam Perseroan, dan juga diembankan tanggung jawab selaku wakil dan salah satu pengurus Perseroan.

Direksi Perseroan seperti layaknya manusia yang mempunyai kedudukan, kewenangan dan kapasitas yang telah ditentukan dalam anggaran dasar (AD) dan Undang-Undang Nomor 40 Tahun 2007 tentang Perseroan Terbatas (UU PT). Dalam menjalankan tugas sebagai perwakilan Perseroan dan tugas pengurusan, Direksi Perseroan harus melakukan tugas dan tanggung jawabnya dengan cara-cara yang baik, layak dan beritikad baik dan penuh tanggung jawab.

\footnotetext{
${ }^{7}$ Gunawan Widjaja, 2004, Tanggung Jawab Direksi atas Kepailitan Perseroan, PT Raja Grafindo Persada,Jakarta, hal. 21.
} 
Meskipun tidak ada suatu rumusan yang jelas dan pasti mengenai kedudukan Direksi dalam suatu Perseroan. Akan tetapi yang jelas Direksi merupakan badan perseroan yang paling tinggi, karena Direksi berhak dan berwenang untuk menjalankan perusahaan, bertindak untuk dan atas nama perseroan (baik di dalam maupun di luar pengadilan) dan bertanggung jawab atas pengurusan dan jalannya perseroan untuk kepentingan dan tujuan perseroan. $^{8}$

Sama halnya dengan civil law sistem dalam hukum common law sistem tugas yang dilakukan anggota Direksi Perseroan dapat diuraikan sebagai berikut:

a) Fiduciary duties of good faith and loyalty ${ }^{9}$

The fiduciary duties are analogous to the duties owed by trustess. Selain itu menurut

\footnotetext{
${ }^{8}$ Try Widiyono, 2005, Direksi Perseroan Terbatas,PT Ghalia Indonesia,Bogor, hal 7.

${ }^{9}$ National Library of Australia Cataloguingin Publication Data, 1987, Duties And Responsibilities of Company Secretaries and Directors in Australia,CCHAustralia Limited,Australia. hal 50.
}

\begin{abstract}
Bernard S Black diartikan sebagai " the decision maker within the company should act in the inerest of the company, and not in their own interest. ${ }^{10}$ Dalam hal ini Direksi bertindak dalam menjalankan pengurusan Perseroan tidak untuk menyalahgunakan kepercayaan yang diberikan padanya semata-mata hanya tuk kepentingan pribadi melainkan tugas dan kewenangan yang diberikan dijalankan untuk kepentingan Perseroan sesuai dengan maksud dan tujuan Perseroan.

Dalam menjalankan Perseroan
\end{abstract} anggota Direksi berdasarkan Fiduciary Duties of good faith dan loyalty dapat dikategorikan sebagai berikut: ${ }^{11}$

a) Director must act bona fade, in what they believe to be in the best interest of the company.

${ }^{10}$ Bernar S Black, 2001, The Principles Fiduciary Duties Of Board Of Director, Asian Roundtable on corporate Governance, Singapore, April, hal 2.

${ }^{11}$ National Library of Australia Cataloguingin Publication Data, Op.Cit, hal. 55. 
b) Director must be exercise their power for purpose for which the are conffered and not for an extraneous purpose.

c) Director must not fetter their disrection to exersicetheir powers.

d) Director must not place themselves in position of conflictof interest without the consentof the company.

Setiap anggota Direksi dalam menjalankan pengurusan berdasarkan jalan pemikirannya sendiri, begitupun dalam mengambil suatu keputusan harus dengan maksud dan tujuan yang benar berasaskan itikad baik dengan mempertimbangkan secara praktis semata-mata untuk kepentingan Perseroan.

2. Duties of skill and care.

Duties of skill and care ini didasari pada duty to exercesi care and diligence. Melihat kewajiban ini maka Direksi dalam menjalankan pengurusan harus dengan kehatihatian. Dan seorang Direksi dituntut untuk mengambil keputusan yang tepat dan cepat demi kepentingan Perseroan. Untuk melindungi setiap keputusan yang dibuat oleh Direksi berdasarkan kewenagan dan itikad baik dengan kehati-hatian maka terdapat prinsip business of jugdement.

Sehingga ketika kesalahan atau kelalaian itu datang, maka resiko harus dapat dipertanggungjawabkan. Setiap orang yang hidup pasti akan mengalami dan akan menghadapi risiko atas hidupnya sendiri, hal ini diakibatkan ketidaktahuannya mengenai peristiwa yang akan ia alami secara pasti.

Dalam suatu Perseroan Terbatas keberadaan Direksi ibarat nyawa bagi perseroan. Tidak mungkin suatu Perseroan tanpa adanya Direksi. Sebaliknya tidak mungkin ada Direksi tanpa adanya Perseroan. Oleh karena itu, keberadaan Direksi bagi Perseroan Terbatas sangat penting.

Direksi diberikan kepercayaan oleh seluruh pemegang saham melalui mekanisme Rapat Umum Pemegang Saham untuk menjadi organ Perseroan yang akan bekerja untuk kepentingan Perseroan, serta kepentingan seluruh pemegang saham yang mengangkat dan 
mempercayakan sebagai satu-satunya organ yang mengurus dan mengelola Perseroan.

\section{Dalam}

menjalankan kepengurusan dan perwakilan Perseroan, Direksi harus bertindak secara hati-hati, patut atau sebaikbaiknya sesuai dengan kewenangan yang diberikan dalam anggaran dasar. Seandainya dalam pengurusan dan perwakilan perseroan tersebut Direksi melakukan perbuatan atau tindakan yang melanggar batas kewenangan atau sesuatu ketentuan yang telah ditetapkan dalam anggaran dasar, maka kepadanya dapat dimintai pertanggungjawaban.

Oleh karena itu seorang Direksi harus berhati-hati dalam melaksanakan tugasnya (duty of care). Selain itu seorang Direksi dalam melaksanakan tugasnya tersebut tidak boleh mengambil keuntungan untuk dirinya sendiri atas perusahaan (duty of loyalty). Pelanggaran terhadap kedua prinsip tersebut dalam hubungan fiduciary duty dapat menyebabkan Direksi untuk dimintakan pertanggungjawaban hukumnya secara pribadi terhadap perbuatan yang dilakukannya baik terhadap pemegang saham ataupun pihak lainnya.

Fiduciary duty seorang Direksi dalam hal ini adalah tugas yang terbit secara hukum (by the operation of law) dari suatu hubungan fiduciary antara Direksi dengan Perseroan yang dipimpinnya, yang menyebabkan Direksi berkedudukan sebagai trustee dalam pengertian hukum trust sehingga seorang Direkai harus memiliki kepedulian dan kemampuan (duty care and skill), itikhad baik, loyalitas dan kejujuran terhadap perusahaan dengan derajat yang tinggi.

Teori wewenang yang diterapkan dalam menjalankan pengurusan Perseroan ini terkait dengan pengertian dari Malaya SP Hasibuan yang mana authority adalah kekuasaan yang sah dan legal yang memiliki seseorang untuk memerintah orang lain, berbuat atau tidak berbuat sesuatu. ${ }^{12}$

${ }^{12}$ Malayu Sp Hasibuan, 2011, Manajemen Dasar, Pengertian, dan Masalah, Bumi Aksara, Jakarta hal.64. 
Menurut louis A Allen seperti dikutip Malayu mengatakan bahwa: ${ }^{13}$

"authority sum if the power and right entrusted to make possible the performance of the work delegated. “

Artinya wewenang adalah

sejumlah kekuasaan (power)

dan hak (right) yang

didelegasikan pada suatu

jabatan.

Sedangkan menurut Harold Koontz dan Cyril O Donnel yang menyatakan $:^{14}$

Authority is legal or right full power a right to command or to act.

Artinya wewenang adalah

kekuasaan yang sah, suatu hak

untuk memerintah atau

bertindak.

Dari pendapat para sarjana diatas dapat ditarik suatu kesimpulan bahwa wewenang merupakan dasar untuk bertindak, berbuat, dan melakukan kegiatan atau aktivitas dalam suatu perusahaan.

\footnotetext{
${ }^{13}$ Ibid,dikutip dari Louis A Allen oleh Melayu SP Hasibuan dalam Manjemen Dasar, Pengertian, dan Masalah, Bumi Aksara, Jakarta.

$$
{ }^{14} \text { Ibid. }
$$
}

a. Hubungan antara Pemegang Saham, dan Direksi Perseroan Terbatas.

Perseroan Terbatas sebagai badan hukum dalam melakukan perbuatan hukum mesti melalui pengurusnya. Tanpa adanya pengurus badan hukum itu tidak akan dapat berfungsi. Ketergantungan antara badan hukum dan pengurus menjadi sebab mengapa antara badan hukum dan pengurus melahirkan hubungan fidusia (fiduciary duties) di mana pengurus selalu menjadi pihak yang dipercaya bertindak dan menggunakan wewenangnya hanya untuk kepentingan Perseroan semata. Perseroan Terbatas sebagai badan hukum (legal entity) merupakan badan hukum mandiri (persona standi in judicio) yang memiliki sifat dan ciri kualitas yang berbeda dari bentuk usaha yang lain. ${ }^{15}$

$$
\text { Hubungan antara Direksi dan }
$$

Perseroan selain didasarkan hubungan kerja, direksi juga memiliki hubungan fidusia dengan Perseroan. Direksi memiliki

\footnotetext{
${ }^{15}$ G. Rai Widjaya, 2005,Hukum
} Perusahaan, cet. 4, PT Megapoin, Jakarta,hal. 142. 
kedudukan fidusia (fiduciary

position) di dalam Perseroan. ${ }^{16}$

Fiduciary duty Direksi akan memberikan perlindungan yang berarti bagi Pemegang saham dalam pelaksanaan pengurusan Perseroan. Dikarenakan pemegang saham dan Perseroan tidak dapat sepenuhnya melindungi dirinya sendiri dari tindakan Direksi yang merugikan di mana Direksi bertindak atas nama perusahaan dan pemegang saham. Maka untuk menghindari penyalahgunaan aset-aset perusahaan dan wewenang oleh Direksi dengan begitu Direksi dibebankan fiduciary duty.

Direksi sebagai organ Perseroan secara historis, pada prinsipnya terdapat teori fiduciary duties yang dimana dibebankan pada Direksi. Karena itu banyak argumen dan yurisprudensi yang telah dibuat untung tanggung jawab Direksi dalam pelaksanaan hubungan tugas fiduciary antara Direksi dengan Perseroan ini. Namun dalam perkembangannya prinsip fiduciary

${ }^{16}$ Simon Fisher, et.al, 2001,Corporation Law, Butterworths, Australia,hal.136. duty ini oleh Direksi sampai pada batas-batas tertentu dikembangkan dan diterapkan pula terhadap beberapa pihak lain dalam Perseroan yaitu pihak pemegang saham dan pekerja di perusahaan tersebut.

Doktrin duty of care, mewajibkan direktur dan management untuk berperilaku hati-hati sebagaimana orang-orang berperilaku dalam situasi yang sama. Jika direktur melanggar duty of care dan mengakibatkan perusahaan menderita kerugian financial, maka pengadilan akan memutuskan bahwa direktur dan manajement bertanggung jawab secara pribadi untuk membayar ganti rugi kepada perusahaan. Sebaliknya, jika direksi dan management menyetujui suatu transaksi dengan mengabaikan duty of care dan transaksi tersebut belum dilakukan maka pengadilan akan memberlakukan injuction untuk mencegah transaksi tersebut. ${ }^{17}$

Kriteria atau standar kehatihatian dapat dibagi dalam beberapa macam, yaitu :

${ }^{17}$ Suharnoko, 2004, Hukum Perjanjian, Teori Dan Analisa Kasus, Ed. Pertama, Cet.ke-6, Prenada Media Group,Jakarta,hal.151-152. 
1) Standar dasar, bahwa direksi harus bertindak seperti orang biasa yang berhati-hati dalam situasi yang sama :

a) Jika seseorang sudah duduk sebagai seorang direksi maka dia dikenai duty of care, meskipun orang tersebut hanya boneka;

b) Tanggung jawab atas pelanggaran duty of care hanya diberlakukan jika direktur melakukan tindakan yang sangat ceroboh atau gross negligence.

2) Standar objektif, artinya direksi yang mempunyai kemampuan dibawah rata-rata orang biasa dalam posisi direksi harus memenuhi standar rata-rata orang biasa. Sebaliknya, direksi yang mempunyai keahlian khusus, harus mempergunakan keahlia khusus tersebut.

3) Menguntungkan keputusan kepada nasihat ahli dan komite. Direksi berhak mengambil keputusan berdasarkan nasihat ahli dan komite, akan tetapi hal tersebut harus masuk akal dalam situasi tertentu.
4) Kelalaian yang pasif, direksi tidak bertanggung jawab atas kelalaiannya karena tidak mengetahui kesalahan yang dilakukan oleh management dan pegawai. Akan tetapi jika dia mengetahui fakta yang mengarah kedugaan adanya perbuatan menyimpang, maka dia tidak dapat menutup mata atas fakta itu. Dalam suatu perusahaan besar, direksi yang tidak melakukan mekanisme untuk memonitor suatu perbuatan menyimpang, seperti internal accounting control atau komite audit, mungkin akan dianggap melanggar duty of care.

5) Sekalipun direksi melanggar duty of care, akan tetapi dia hanya bertanggung jawab atas kerugian jika perbuatanya merupakan proximate cause atau sebab terdekat dari timbulnya kerugian. ${ }^{18}$

Dengan demikian Pelaksanaan pengurusan Perseroan dengan itikad baik dan penuh tanggung jawab

${ }^{18}$ Ibid,hal. 152-153. 
berarti mewajibkan Direksi untuk melaksanakan tugasnya dengan rajin, kehati-hatian, serta trampil dalam menyikapi segala persoalan.

Dengan demikian yang harus diperhatikan Direksi bukan hanya perusahaan yang dipimpinnya, melainkan kepentingan pemegang sahan dan pekerja di perusahaan tersebut. Direksi juga harus mampu mengartikan dan melaksanakan kebijakan Perseroan secara baik demi kepentingan Perseroan. Dengan demikian Direksi harus memiliki standar integritas dan loyalitas yang tinggi serta bertindak untuk kepentingan Perseroan.

\section{b. Tindakan Direksi Yang Tidak Sesuai dengan Anggaran Dasar Perseroan Terbatas.}

Direksi dituntut untuk bertanggung jawab penuh atas pengurusan perseroan untuk kepentingan dan tujuan perseroan, serta mewakili perseroan, baik di dalam maupun di luar pengadilan. Tugas dan fungsi utama Direksi, menjalankan dan melaksanakan pengurusan Perseroan. Jadi
Perseroan diurus, dikelola dan dimanage oleh Direksi.

Segala tindakan Direksi yang melampaui batas kewenagan yang sudah diatur dalam anggaran dasar dan dan undang-undang Perseroan maka sudah dianggap melakukan suatu tindakan pelanggaran.

Direksi dalam melaksanakan fungsi dan kewenangan dalam pengurusan itu, tujuannya tidak wajar maka tindakan pengurusan yang demikian dikategorikan sebagai pengurusan yang dilakukan dengan itikad buruk.

Apabila tindakan Direksi yang tidak sesuai dengan kepentingan Perseroan dalam hal ini terkait dengan adanya benturan kepentingan (avoid conflict of interst), yakni Direksi mempergunakan aset kekayaan dan kepentingan Perseroan untuk maksud mencari keuntungan bagi dirinya sendiri.

Hal-hal yang perlu dihindari oleh anggota Direksi dalam menjalankan pengurusan Perseroan yaitu adanya benturan kepentingan, maka ada ruang lingkup kewajiban anggota Direksi antara lain: 
1. Kewajiban untuk tidak mempergunakan uang dan kekeyaan Perseroan untuk kepentingan pribadi. Apabila kewajiban ini dilanggar dan mengakibatkan Perseroan mengalami kerugian anggita Direksi tersebut :

-Dikualifikasi melakukan perbuatan melawan hukum berdasarkan Pasal 1365 KUHPerdata.

- Atas perbuatan itu, anggota Direksi yang bersangkutan diancam dengan pertanggung jwaban perdata (civil liabiility) dan bahakan juga dapat dituntut pertanggungjawaban pidana (criminal liability) menggelapkan uang

Perseroan berdasar Pasal 372 KUHAP atau penipuan Pasal 378 KUHAP.

2. Mempergunakan informasi Perseroan untuk kepentingan pribadi. Perbuatan ini dikategorikan melakukan pelanggaran terhadap kewajiban yang dipercaya (breach of fiduciary duty).
3. Tidak mempergunakan posisi untuk memperoleh keuntungan pribadi seperti menirima sogokan, atau perbuatan yang dikategorikan breach of fiduciary duty.

4. Tidak menahan atau mengambil sebagian dari keuntungan perusahaan untuk kepentingan pribadi. Mengambil atau menahan sebagian keuntungan Perseroan untuk kepentingan pribadi merupakan sebagai perbuatan yang merahsiakan keuntungan oleh anggota Direksi yang bersangkutan.

5. Dilarang melakukan transaksi dengan Perseroan. Dalam hal ini anggota Direksi dilarang melakukan transaksi antara pribadinya dengan

Perseroan :

-Dalam hal yang demikian, anggota Direksi telah melanggar kewajiban yang melarangnya masuk dalam kontrak atau transaksi yang dilarangyang wajib diurus sendiri. 
- Perbuatan itu dikategorikan sebagai tindakan pihak berkepentingan (party at interest). Larangan ini tidak bolaeh dilanggar oleh anggota Direksi baik langsung atau tidak langsunng termasuk anggota keluarganya atau temannya.

6. Larangan bersaing dengan Perseroan, anggota Direksi dalam menjalankan kewajibannya mengurus Perseroan dilarang bersaing dengan Perseroan. Tindakan ini dikategorikan sebagai duty conflict dan dikualifikasikan sebagai breach of his fiduciary duty and good faith duty.

The law relating to the entitlement of directors to indemnity is differnt, but the imprtant thing to note is that, if a director is found to have committed a wrong the director may well be personally liable for any damage suffered by third party as a consequence. ${ }^{19}$

${ }^{19}$ Geoffrey Gibson, 2003, Law For Directors, National Library of Australia Cataloguing in Publication, Australia, hal.77.
Demikian luasnya jangkauan atau ruang lingkup suatu pengurusan yang dilakukan anggota Direksi harus dengan itikad baik. Sebab apabila ada perjanjian yang dibuat dalam keadaan demikian maka perjanjian tersebut tidak batal karena atau demi hukum melainkan dapat menuntut pembatalan perjanjian itu yang disertai dengan tuntutan ganti rugi yang dialami atau menuntut keuntungan yang diambil dan ditahan anggota Direksi yang demikian.

\subsection{TANGGUNG JAWAB DIREKSI DALAM PERSEROAN TERBATAS SEBAGAI BADAN HUKUM YANG MANDIRI .}

Tanggung jawab adalah (responsibility) adalah keharusan untuk melakukan semua kewajiban dan tugas-tugas yang dibebankan kepadanya sebagai akibat dari wewenang yang diterima atau dimilikinya. Setiap wewenang akan menimbulkan hak (right), tanggung jawab (responsibility), kewajibankewajiban untuk melaksanakan dan mempertanggung jwabkan (accountability). Tegas bahwa 
tanggung jawab tercipta, karena penerimaan wewenang. Tanggung jawab sama besarnya dengan wewenang yang dimiliki. ${ }^{20}$ Tanggung jawab dapat berlangsung terus menerus atau berhenti apabila tugas tertentu yang dibebankan kepadanya telah selesai dilaksanakan. Dalam Perseroan biasanya antara wewenang dengan tanggung jawab memiliki tinggkatan yang sama. Sehingga wewenang seorang Direksi memberikan kepadanya kekuasaan untuk membuat serta menjalankan keputusan-keputusan yang berhubungan dengan bidang tugasnya yang telah ditetapkan, dan tanggung jawab dalam bidang tugasnya menimbulkan kewajiban baginya untuk melaksanakan tugastugas tersebut dengan jalan menggunakan wewenang yang ada untuk mencapai tujuan Perseroan.

Australian the Corporation Act 2001 dalam section 181-183 yaitu mengatur juga hal yang sama dimana Direksi harus bertindak dengan itikad baik dan tidak menyalahgunakan hal.70. posisi dan informasi yang dia dapat karena kedudukannya sebagai Direksi (Company Directors must act in good faight in the best interest of proper purpose not misuses one's position within the company and not misuse information obtained because of their potition as a director or officer the company). ${ }^{21}$

Sebagai konsekuensi yuridisnya, Direksi sebagai pemegang kuasa tidak boleh bertindak melebihi dari kekuasaan yang diberikan kepadanya. Adapun batasan tersebut diatur dalam Anggaran Dasar. Terdapat 3 (tiga) teori tanggung jawab menurut Sidartha yaitu ${ }^{22}$ :

- $\quad$ Tanggung jawab yang berdasarkan kelalaian dan kesalahan;

- Tanggung jawab yang berdasarkan ingar atau wanprestasi;

- $\quad$ Tanggung jawab mutlak. Act 2001 .

${ }^{21}$ Liat Australian The Corporation

${ }^{22}$ Sidartha, 2006, Hukum Perlindungan Konsumen Indonesia, PT Gramedia Widiasara Indonesia, Jakarta, hal 98. 
Dari ketiga teori tanggung jawab tersebut, tanggung jawab mutlak adalah merupakan doktrin yang terbaru. Seperti yang terdapat dalam Undang-undang No. 8 Tahun 1999 tentang Perlindungan Konsumen. Prinsip tanggung jawab berdasarkan kesalahan dengan 2 (dua) modifikasi yaitu : Pertama, prinsip tanggung jawab berdasarkan praduga bersalah/lalai atau produsen sudah dianggap bersalah, sehingga tidak perlu dibuktikan kesalahannya (presumption of negligence). Kedua, prinsip untuk selalu bertanggung jawab dengan beban pembuktian terbalik (presumption of liability principle).

Di samping tugas utama direksi tersebut, Rudhi Prasetya menyatakan bahwa termasuk sebagai tugas direksi dalam perbuatan dan kejadian seharihari tersebut, menurut anggaran dasar: ${ }^{23}$

1) menandatangani saham-saham yang dikeluarkan, bersamasama komisaris;

${ }^{23}$ Subhan, M.Hadi, 2008, Hukum Kepailitan, Prinsip, Norma dan Praktik di Peradilan, edisi pertama, cet.ke-1, Prenada Media Group, Jakarta,hal 227.
2) menyusun laporan neraca untung rugi perseroan pada akhir tahun, sebagai pertanggungjawaban direksi, dengan menyampaikannya dan meminta untuk disahkan oleh Rapat Umum Pemegang Sahara (RUPS);

3) melakukan pemanggilan RUPS dan memimpin RUPS (khusus untuk PT terbuka RUPS dipimpin oleh komisaris).

Tugas dan wewenang direksi tersebut di atas penting untuk diketahui sebelum menganalisis mengenai tanggung jawab direksi. Rudhi Prasetya menyatakan bahwa : 24

"jika berbicara mengenai pertanggungjawaban, “ maka dapat dilihat dari segi hubungan ekstern dan segi hubungan intern. Tanggung jawab ekstern adalah tanggung jawab sebagai dampak dalam hubungan dengan pihak luar. Sedangkan tanggung jawab intern adalah dampak dari hubungan si pengurus sebagai organ terhadap

$$
{ }^{24} \text { Ibid. }
$$


organ lainnya, yaitu institusi komisaris dan/atau rapat umum pemegang saham . Dilihat dari substansinya, maka tanggung jawab direksi perseroan terbatas dibedakan setidak-tidaknya menjadi empat kategori, yakni: 1) tanggung jawab berdasarkan prinsip fiduciary duties dan duty to skill and care;

2) tanggung jawab berdasarkan doktrin manajemen ke dalam (indoor manajement rule); 3) tanggung jawab berdasarkan prinsip Ultra vires; dan

4) tanggung jawab berdasarkan prinsip piercieng the corporate veil.

Dalam kaitannya dengan tanggung jawab Direksi, Darian M.Ibrahim membagi timbul pertanggung jawaban pribadi dan waktu timbul pertanggung jawaban tanggung renteng. Dimana yang dimaksud dengan pertanggung jawaban secara pribadi yaitu disaat seorang Direksi tidak melaksanakan duty of loyal (good faight, conflict of interst or self interest). Sedangkan waktu timbulnya duatu petanggung jawaba secara renteng dimana Diireksi tidak melakukan duty of care dengan tidak melaksanakan standart of conduct. Setiap anggota Direksi bertanggung jawab secara pribadi atas kerugian Perseroan bila yang bersangkutan bersalah atau lalai menjalankan tugas dalam melakukan pengurusan Perseroan. Dalam hal ini apabila Direksi terdiri dari dua atau lebih maka kerugian Perseroan yang diakibatkan oleh kesalahan Direksi menjadi tanggung jawab secara tanggung renteng.

Tanggung jawab secara tanggung renteng Direksi sebagai suatu kesatuan adalah tanggung jawab bersama secara kolektif yang berlaku bagi seluruh anggota Direksi. Dengan diberikannya tanggung jawab kolegial ini dimaksudkan agar sesama Direksi:

1. Dilakukan keterbukaan atau transparansi atau disclosure sesama anggota Direksi mengenai setiap tindakan dan atau perbuatan hukum yang hendak diambil atau telah diambil oleh satu atau lebih 
masing-masing

anggota

Direksi atas hal-hal yang berada dalam kewenangnyan.

Demikian pula kepemilikan saham yang dimiliki anggota Direksi yang bersangkutan dan atau keluarga dalam Perseroan Terbatas dan Perseroan lain agar dalam daftar khuss.

2. Dilakukan check and balance tentang kegiatan tindakan atau keputusan yang menghendaki agar sedapat mungkin atau seyogyanya diambil berdasarkan pada keputusan rapat Direksi. Dengan pertanggung jawaban secara tanggung renteng ini diharapkan dapat terjadi saling mengawasi di antara semua anggota Direksi Perseroan atas setiap perbuatan, tindakan atau keputusan Direksi yang doikhawatirkan dapat mengakibatkan terjadinya pelanggaran terhadap fiduciary duty, yang menyebabkan tidak berlakunya businnes judgement rule. a. Tanggung Jawab Direksi

Terhadap Pengurusan

Perseroan Terbatas terkait Doktrin Ultra Vires dan Doktrin Piercing the Corporate Veil.

Direksi yang tidak sesuai dengan maksud dan tujuan Perseroan yang ditentukan dalam Anggaran Dasar, maka dianggap melakukan tindakan yang melampaui kapasitas yang diberikan Perseroan. Tindakan yang tidak sesuai dengan kapasitas Perseroan berkaitam dengan doktrin ultra vires. Ultra vires berasal dari bahasa latin yang berarti di luar atau melebihi kekuasaan (outside the power), yakni di luar kekuasaan yang diijinkan oleh hukum terhadap badan hukum. Terminologi ultra vires dipakai khususnya terhadap tindakan Perseroan yang melebihi kekuasaannya sebagaimana diberikan oleh Anggaran Dasar atau peraturan yang melandasi pembentukan Perseroan Tersebut.

Di Australia, sebagaimanana menurut Philiip Lepton, Pengadilan Australia secara umum, tabu untuk membuka cadar perseroan 
tertabatas. $^{25}$ Penerobosan cadar perseroan di Astralia sangat jarang terjadi.

Dari buku Understanding Company Law, maka penulis dapat menyebutkan beberapa alasan yang menyebabkan pengadilan di Australia menerobos cadar perseroan terbatas diantara adalah :

1. where a company is used as vehicle for fraud;

2. if a company has been used so as to avoid a legal duty;

3. if the incorporation of a company can be seen to be a sham77 or the company is mere "puppet" of its controller;

4. if a company knowingly participates in a director's breach of her or hisfiduciary duties.

Maka dapat dikatakan bahwa penerobosan tanggung jawab terbatas pada perseroan terbatas di Australia dapat dilakukan antara lain dalam hal perseroan dipergunakan sebagai alat untuk melakukan penipuaan, penghindaran suatu kewajiban

${ }^{25}$ Phillip and lipton dan Abe Herzberg, 1993, Understanding Company Law, Perth the Law book Company Limited,hal.31 hukum, perseroan digunakan sebagai topeng semata oleh pengendali, atau jika direksi melanggar kewajiban fidusiarinya.

Doktrin ultra vires dimaksudkan untuk melindungi para investor atau pemegang saham, yaitu untuk mencegah Direksi melakukan perbuatan ultra vires atau kemudian untuk memperoleh ganti kerugian dari Perseroan. Hal ini disebutkan sebagai aspek internal dari ultra vires, sedangkan aspek eksternalnya dari ultra vires adalah permasalahan apakah kontrak ultra vires mengikat pihak ketiga Perseroan yang bersangkutan. Pada dasarnya suatu kontrak ultra vires adalah tidak sah (unlawful), batal demi hukum dan tidak dapat disahkan kemudian oleh suatu RUPS. Dengan demikian, Perseroan dapat menolak melaksanakan kewajiban berdasarkan kontrak karena tidak mengikat Perseroan. Dengan begitu kewajiban menjadi tanggung jawab pribadi Direksi.

b. Tanggung Jawab Sosial dan Lingkungan Perseroan dalam 
Sistem Hukum Indonesia dan Australia.

Kebijakan tanggung jawab sosial (Corporate Social Responsibility selanjutnya disingkat dengan CSR) memberikan nilai dalam rencana strategis kegiatan perusahaan sehari-hari. Penerapan tanggung jawab sosial oleh perusahaan berarti bahwa perusahaan bukan hanya merupakan entitas bisnis yang hanya berusaha mencari untung semata, tetapi perusahaan merupakan satu kesatuan degan ekonomi, sosial, dan lingkungan di mana perusahaan beroperasi. Direksi dan pegawai perusahaan seharusnya lebih menyadari pentingnya suatu tanggung jawab sosial ( CSR) karena CSR dapat memberikan perlindungan hak asasi manusia bagi buruh dan perlindungan lingkungan bagi masyarakat sekitar juga para pekerjanya ${ }^{26}$ Kehadiran $C S R$ dalam bisnis perusahaan menjadi lebih jelas dengan adanya perkembangan

${ }^{26}$ Kristina K.Hermann, 2004, Corporate Socual Rensponsibility and Sustainable Development, The European Union Initiative asa Case Study, 11 Indiana Journal of Global Legal Studies, hal. 206. globalisasi. Hal ini dapat terlihat dari .27

a) Pengelolaan risiko;

b) Perlindungan dan meningkatkan reputasi dan image perusahaan;

c) Membangun kepercayaab dan license to operate bagi perusahaan.

d) Meningkatkan efisiensi sumber daya yang ada dan meningkatkan akses terhadap modal;

e) Merespon atau mematuhi peraturan yang berlaku

f) Membina hubungan baik dengan stakeholder seperti pekerja, konsumen, partner bisnis, investor, yang mempunyai tanggung jawab secara sosial, regulator dan komunitas di mana perusahaan broperasi;

g) Mendorong pemikiean yang inovatif

h) Membangun kesempatan untuk mengikuti pasar masa depan.

Dilihat dari sudut pandang hukum bisnis setidaknya ada dua tanggung jawab yang harus dipenuhi dalam etika bisnis taitu tanggung jawab hukum (legal responsibility) yang meliputi aspek perdata (civil

27 Ibid, hal. 207. 
liability) dan aspek pidana (crime liability) dan aspek tanggung jawab sosial ( social responsibility) yang dibangun di atas landasan norma moral yang berlaku di dalam masyarakat.

Selain konsep CSR diatas, terdapat konsep CSR yang dikembangkan oleh Archie B. Carrol yang disebut dengan piramida CSR. Hal ini CSR merupakan kepedulian perusahaan yang didasari tiga prinsip dasar yang dikenal dengan istilah triple bottom line, yaitu profit, people, dan plannet (3P) yaitu: ${ }^{28}$

1. Profit. Perusahaan tetap harus berorientasi untuk mencari keuntungan ekonomi yang memungkinkan untuk terus beroperasi dan berkembang.

2. People. Perusahaan harus memiliki kepedulian terhadap kesejahteraan manusia. Beberapa perusahaan mengembangkan program CSR seperti pemberian beasiswa bagi pelajar sekitar perusahaan, pendirian sarana pendidikan dan kesehatan, penguatan kapasitas ekonomi lokal,

${ }^{28}$ www.google.com, diakses tanggal 2 juli 2012. dan bahkan ada perusahaan yang merancang berbagai skema perlindungan sosial bagi warga setempat.

3. Plannet. Perusahaan peduli terhadap lingkungan hayati. Beberpa program CSR yang berpijak pada prinsip ini biasanya berupa penghijauan hidup lingkungan hidup, penyediaan sarana pengembangan pariwisata (ekoturisme).

peraturan mengenai perusahaan di Australia ini merupakan Pasal sentral tugas-tugas bagi direktur perusahaan. Dalam undang-undang ini terdapat 2 pasal yang berhubungan dengan pengaturan corporate social responsibility bagi perusahaan, yaitu :

a) Section $299(1)(f)$

“if the entity's operations are subject to any particular and significant environmental

regulation under a law of the Commonwealth or of a State or Territory-give details of the entity's performance in relation toenvironmental regulation."

b. section $1013 \mathrm{DA}(1)$ 
"ASIC may develop guidelines that must be complied with where a Product Disclosure Statement makes any claim that labour standards or environmental, social or ethical considerations are taken into account in theselection, retention or realisation of the investment"

Dalam undang-undang perusahaan Australia section $1013 \quad D A$ mengandung pengertian bahwa undang-undang tersebut memaksakan perusahaanperusahaan untuk memenuhi kewajiban-kewajiban dalam pemberian pensiun, asuransi jiwa dan pengaturan dana untuk memperlihatkan tingkat seberapa mereka memperhatikan lingkungan, sosial, tenaga kerja dan standar etika di dalam memutuskan investasi. Sedangkan Section 299(1) (f) mengandung penjelasan bahwa perusahaan untuk memasukkan ke dalam laporan tahunan mereka harus adanya rincian pelanggaran terhadap hukum lingkungan dan lisensi. Melihat penjelasan dari sections tersebut di Australia terjadi perdebatan dikalangan para pengusaha karena perusahaanperusahaan harus mampu mempertimbangkan kepentingan dari stakeholders selain dari shareholders. Peraturan selain dari Corporations Act 2001 memaksakan kewajiban-kewajiban tambahan kepada para direktur perusahaan dalam hal hubungan mereka dengan karyawan dan lingkungan.

Pengaturan terkait masalah corporate social responsibility, dalam Corporations Act 2001 tidak diatur secara menyeluruh. Sehingga menurut pemerintah australia perlu adanya batasan-batasan bagi perusahaan-perusahaan yang ada di Australia dalam menjalankan usahanya. Dalam pengaturan terkait penerapan tanggung jawab sosial dan lingkungan (Corporate Social Responsibility) tidak akan terlepas dari 2 teori yaitu Teori legitimasi dan Teori Stakeholder.

Australia pengaturannya memang masih bersifat sukarela,tidak mengikat secara wajib bagi perusahaan untuk melakukan 
CSR akan tetapi di australia mempunyai standar-standar atau Guidelines dan publikasi kepada masyarakat akan eksistensi suatu perusahaan. Dan membiarkan agar masyarakat yang menilai suatu perusahaan, serta akan memakai produknya atau tidak. Dalam Corporations Act 2001 memang tidak diatur secara detail terkait CSR akan tetapi baik dalam section 299 $(1)(f)$ dan $1013 D(1)$, bahwa dalam laporan tahunan perusahaanperusahaan yang ada di Australia harus terakomodasi kepentingan stakeholder baik internal maupun eksternal.

\section{KESIMPULAN DAN SARAN}

\section{1 Kesimpulan}

Adapun kesimpulan dari uraian bab-bab di atas yaitu :

1. Direksi adalah organ Perseroan yang memiliki kewenangan untuk melakukan pengurusan Perseroan. Direksi berkewajiban untuk menjalankan pengurusan Perseroan sebaik-baiknya dan sesuai dengan maksud dan tujuan Perseroan. Dalam menjalankan pengurusan Direksi tidak mempergunakan kekayaan Perseroan untuk kepentingan pribadi serta tidak mengambil keuntungan pribadi dengan mempergunakan harta kekayaan dan atau fasilitas yang diberikan oleh Perseroan.Dalam menjalankan pengurusan Perseroan sejalan dengan maksud dan tujuan Perseroan untuk kepentingan Perseroan sematamata. Landasan transplantasi prinsip fiduciary yang diemban Direksi dalam menjalankan pengurusan di sistem hukum Indonesia, yaitu rights in personam dan rights in rem merupakan dasar dari transplantasi prinsip fiduciary berkaitan dengan justifikasi transplantasi, prinsip fiduciary tidak bertentangan dengan nilainilai kesejahteraan sosial, efisiensi dan keadilan yang terkandung dalam UndangUndang Dasar 1945 sebagai basic norm. Hasil perbandingan menunjukkan bahwa sistem pengaturan di Indonesia dan Australia lebih condong menggunakan model mandatory 
dan bukan model enabling karena didasari oleh kondisi struktur kepemilikan modal.

2. pelaksanaan tugas Direksi senantiasa dikaitkan dengan kewajiban melaksanakan fiduciary duty. Dalam tugasnya tidak melaksanakan fiduciary duty yang sesuai dengan standart of conduct, maka anggota Direksi dapat dimintakan pertanggungjawaban baik secara pribadi maupun tanggung renteng apabila Perseroan mengalami kerugian diakibatkan kelalaian dan kesalahan dalam menjalankan pengurusan Perseroan.

\section{Saran}

Adapun saran penulis yang ingin disampaikan sebagai dasar dalam penelitian ini yaitu :

1. Bagi Direksi dalam pelaksanaan tugas senantiasa dikaitkan dengan menjalankan kewajiban fiduciary duty, Oleh karena apabila tidak dilaksanakan fiduciary duty dengan itikad baik serta sesuai dengan maksud dan tujuan Perseroan anggota Direksi anggota Direksi tidak berhak mendapatkan perlindungan business judgemnt rule.

2. Kewenangan yang dilakukan berdasarkan prinsip fiduciary, khususnya pada undang-undang baik di Indonesia maupun Australia nampak sebagai incomplete law dan perlu diinterpretasikan oleh lembaga peradilan. Adanya perbedaan mengenai kedewasaan pemberlakuan kewajiban fiduciary di kedua negara. Oleh karena itu, Indonesia melakukan transplantasi lanjutan agar kewajiban fiduciary dapat berdayaguna. 


\section{DAFTAR PUSTAKA}

\section{Buku.}

Agus Budiarto, 2002,Kedudukan Hukum Tanggung Jawab Pendiri Perseroan Terbatas, Cet. I, Ghalia Indonesia,Jakarta, .

Rudhi Prasetyo, Kedudukan Mandiri Perseroan Terbatas disertai dengan ulasan menurut UU No,1 tahun 1995 tentang Perseroan Terbatas, Cet,ke I, PT Citra Aditya Bakti, Bandung, 1995.

Munir Fuady, 2008,Perseroan Terbatas Paragdigma Baru, Cetakan 3, PT Citra Aditya Bakti, Bandung, hal.8. (selanjutnya disingkat Munir Faudy I)

Munir Fuady, 1996,Hukum Bisnis Dalam Teori dan Praktek buku ke satu, PT Citra Aditya Bakti, Bandung.

Pedoman Penulisan Usulan Penelitian dan Penulisan Tesis Ilmu Hukum Program Studi Magister Ilmu Hukum Program PascaSarjana, 2006,UNUD

Peter Mahmud Marzuki,2007, Penelitian Hukum, Jakarta.

Gunawan Widjaja, 2004, Tanggung Jawab Direksi atas Kepailitan Perseroan, PT Raja Grafindo Persada,Jakarta.

Try Widiyono, 2005, Direksi Perseroan Terbatas,PT Ghalia Indonesia,Bogor.

National Library of Australia Cataloguingin Publication Data,
1987, Duties And Responsibilities

of Company Secretaries and

Directors in

Australia,CCHAustralia Limited,Australia.

Bernar S Black, 2001, The Principles Fiduciary Duties Of Board Of Director, Asian Roundtable on corporate Governance, Singapore, April.

G. Rai Widjaya, 2005,Hukum Perusahaan, cet. 4, PT Megapoin, Jakarta.

Simon Fisher, et.al, 2001, Corporation Law, Butterworths, Australia.

Suharnoko, 2004, Hukum Perjanjian, Teori Dan Analisa Kasus, Ed.

Pertama, Cet.ke-6, Prenada Media Group,Jakarta.

Geoffrey Gibson, 2003, Law For Directors, National Library of Australia Cataloguing in Publication, Australia.

Malaya SP Hasibuan, 2011, Manajemen Dasar, Pengertian, dan Masalah, Bumi Aksara,.

Australian The Corporation Act 2001.

Sidartha, 2006, Hukum Perlindungan Konsumen Indonesia, PT Gramedia Widiasara Indonesia, Jakarta.

Subhan, M.Hadi, 2008, Hukum Kepailitan, Prinsip, Norma dan Praktik di Peradilan, edisi 
pertama, cet.ke-1, Prenada Media

Group, Jakarta,hal 227.

${ }^{1}$ Ibid.

Phillip nlipton dan Abe Herzberg, 1993, Understanding Company

Law, Perth the Law book

Company Limited,hal.31

Kristina K.Hermann, 2004,

Corporate Socual Rensponsibility

and Sustainable Development,

The European Union Initiative asa

Case Study, 11 Indiana Journal of

Global Legal Studies, hal. 206.

\section{Bahan Internet}

2 juli 2012

www.google.com, diakses tanggal

\section{DATA PENULIS}

Nama : Shinta Ikayani K

Alamat :Jl. Wirasatya II No 11

Sidakarya.

No Hp. 081805365737 


\section{Jurnal Hukum}

Pengaturan Kewenangan, dan Tanggung Jawab Direksi Dalam Perseroan Terbatas (Studi Perbandingan Indonesia dan Australia)

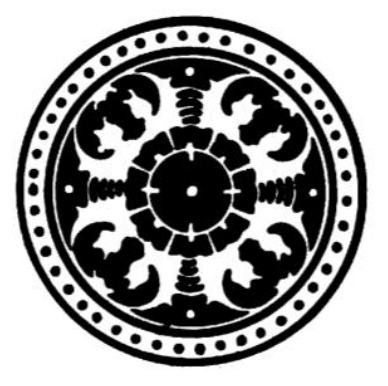

0leh

Shinta Ikayani Kusumawardani

PROGRAM PASCASARJANA

UNIVERSITAS UDAYANA

DENPASAR

2012 